A 'Tropical Storm' photographed from a Rocket Is the June number of the Monthly Weather Reriew, L. F. Hubert and O. Berg, of the United States W'eather Bureau and the United States Naval Research Laboratory, respectively, show and describe the first photographs taken from a rocket of the clouds of a tropical storm. The ascent was made in New Mexico on October 5, 1954, and was not made especially for photography of clouds from above. The photographs were taken by two cameras, one giving black-and-white and the other colour photographs, when the rocket was at a height of a hundred miles. The rocket rolled slowly as it moved so that the cameras scanned successive overlapping strips of the Earth. A composite photograph of the clouds over an area of $1,250,000$ sq. miles is given in the article. The principal feature is a tropical storm centred near Del Rio, Texas, and the spiral structure of the clouds of the storm is clearly visible. This storm moved inland from the Gulf of Mexico and was quite a mild one, giving winds of only 18 knots over Texas. The convection was strong enough, however, to give three inches of rain at Brownsville, Texas, in three-quarters of an hour and more than six inches in three hours. The rocket photographs show two minor vortices the existence of which had not been suspected from the synoptic observations. From the photographs and other evidence, it is found that the axis of the storm extended about seven miles vertically and fifty-five miles horizontally. The slope of the axis fits well with a formula due to Panofsky giving it in terms of the curvature of the horizontal pressure profile and the horizontal gradient of temperature. The authors state that plans are in hand to fire rockets specifically for research into hurricanes and look forward to photography by rocket of the clouds over widespread tropical regions, such as South Equatorial America, which are as yet but little investigated.

\section{Higher Education in the Colonies}

IN a written reply in the House of Commons on December 6 , the Secretary of State for the Colonies, the Right Hon. A. Lennox-Boyd, said that the Government had contributed $£ 6,453,301$ from 1945 to March 31, 1955, towards the capital cost of universities, university colleges and colleges of art, science and technology in the Colonial Territories. This total included $£ 1,710,804$ to University College, Ibadan, $£ 1,087,223$ to Makerere College, and $£ 2,423,129$ to the University College of the West Indies; but not the allocations of $£ 1,019,000$ and $£ 350,000$ to the University of Malaya and the Kumasi College of Technology, respectively, on which no call had yet been made. Although grants towards recurrent costs are not normally made, during the period 1954-55 grants for this purpose of $£ 29,775$ and $£ 24,000$, respectively, had been made to the University College of the West Indies and to Fourah Bay College, Sierra Leone. The total expenditure on education for the current year for the Wost Indies, Gold Coast, Nigeria, East and Central Africa, Malaya and Singapore was estimated at $£ 56,666,967$.

\section{The Tensor Club of Great Britain}

DURING the past two decades the matrix and tensor calculus has found increasing application in the analysis of practical and particular problems in engineering, especially electrical engineering. About five years ago the Tensor Club of Great Britain was formed for the purpose of bringing together engineers and others interested in matrix and tensor analysis, and for spreading information regarding applications. The Club produces the Matrix and Tensor Quarterly, a magazine with about a hundred and sixty pages per volume which is sent out to about a hundred and fifty subscribers. Of the present members of the Club, about a half reside in Great Britain and about a quarter in the United States. There are also members in other countries, including France, Japan and India, and liaison has been established with the Tensor Society of Japan. The Club maintains a small lending library, and reciprocal arrangements exist for the exchange of magazines with the Mathematisch Centrum of Amsterdam, and with two universities in Japan. The membership of the Club is comprised mostly of engineers, physicists, mathematicians and chemists, employed in industry, research establishments, public utility companies and teaching. Information regarding membership can be obtained from S. Austen Stigant, 7 Courtlands Avenue, Hayes, Kent.

\section{Chemical Composition of the Larger Seaweeds}

AN account has been given by D. J. Wort (Canad. $J$. Bot., 33, 4, 323; 1955) of the seasonal variations in the chemical composition of Macrocystis integrefolia and Nereocystis luetkeana growing in the coastal waters of British Columbia. These two seaweeds were collected at two stations at monthly intervals from October 1949 until September 1951. Analyses of fronds and of stipes were made for dry weight, ash, total nitrogen, total phosphorus, sulphur, copper, zinc, iron, ether-solubles, algin, mannitol, fucoidin, and laminarin. Generally speaking, the fronds had a higher content of all substances measured than did the stipes, and the content of the two species of algae showed parallel variation but differed in values. Dry weight and ash were at maxima in autumn and winter and at minima in April and May. During March, total nitrogen, ether-solubles, mannitol, fucoidin and laminarin were at their highest concentration. The plants in July contained the minima of total nitrogen, phosphorus and ether-solubles. The maximum for phosphorus occurred in December, and during this same month fucoidin was at minimum. The variation of sulphur, copper, zinc, iron and algin was such that well-marlsed minima and maxima were not evident. The author points out that while photosynthetic processes in the brown algae are considerably less well understood than they are in green plants, it is probable that phosphorylated mannose compounds are involved in the sequence, mannitol, a hexahydric alcohol, heing important. The fronds of the two algae investigated have their highest mannitol contents during spring and early summer, the period of most active photosynthesis. The scasonal relation. ships of the other products of photosynthesis are also discussed.

\section{Banana Wilt Disease}

Is recent investigations, in Jamaica, of Panama disease or vascular wilt disease of bananas (Fusarium oxysporum $f$. cubense), J. Rishbeth has confirmed earlier findings on the mode and progress of infection and has contributed some new and interesting information on this important disease and on the biology of its causal organism (Ann. Bot., N.S., 19, No. 75, 293; 1955). The pathogen has proved difficult to isolate from soil by plating, but it can be detected in soil by using a suitable host. Thus when small bananas were grown in pots under appropriate 